\title{
New Approaches to the Study of Violence
}

Jeffrey C. Isaac

In his recent book The Better Angels of Our Nature: Why Violence Has Declined, Harvard psychologist Steven Pinker draws upon a wealth of data to argue that the modern world, especially since 1945 , has experienced a dramatic and probably irreversible decline in organized violence. The book has received much critical attention (which will indeed be the topic of future discussion in Perspectives). It is undeniably true that recent decades have seen a decrease in the incidence of, and casualties related to, classic forms of interstate violence, and that in recent years there has been a decline in organized civil war violence as well. At the same time, it is equally true that violence-its threat, its use, its many often-unpredictable consequencesremains an ever-present part of the political landscape throughout the world. The Geneva Declaration on Armed Violence and Development's recent report, The Global Burden of Armed Violence 2011, estimates that since 2004 "more than 526,000 people are killed each year as a result of lethal violence." The report estimates that only around one tenth of these killings-approximately 55,000 per year-are caused by "direct armed conflict," i.e., in organized wars, whether interstate or civil. But it also estimates that hundreds of thousands more are related to gang violence, drug trafficking, transnational organized crime, and other activities that take place in a netherworld beyond law and order, and between "war" and "peace." And it observes that while the categories typically used by governments, multilateral agencies, and NGOs to classify violence-organized vs. interpersonal, conflict-related vs. criminal-serve certain practical purposes, "these distinctions give the misleading impression that different forms and incidents of violence fit into neat and separate categories," whereas in fact these forms of violence are not so neatly distinguished. And beyond the sphere of lethal violence lays a much broader domain of destruction, fear, insecurity, vulnerability, and harm.

One of the most interesting developments in contemporary political science is the emergence of new research agendas that treat violence as a complex phenomenon or range of phenomena that elude simple categorizations, especially the conventional understandings - of "inside" and "outside," "domestic" and "foreign," "comparative politics" and "international relations"- that have long gov- erned the study of violence in our discipline. An important spur to this development was one of the most frequentlycited articles published in our journal's history, Stathis N. Kalyvas's "The Ontology of 'Political Violence': Action and Identity in Civil Wars" (September 2003). As Kalyvas argued, "civil wars are not binary conflicts but complex and ambiguous processes that foster an apparently massive, though variable, mix of identities and actions- to such a degree as to be defined by that mix. Put otherwise, the widely observed ambiguity is fundamental rather than incidental to civil wars, a matter of structure rather than noise." To treat such ambiguity as fundamental to civil conflict is to open up a range of questions about the diverse motivations and interests in play in violent conflicts; the shifting relationships and alliances within and between insurgent organizations; the importance of local and regional as well as national and transnational dynamics; the different ways in which violence is used as a strategy and as a tactic, and the ways in which it sometimes has a veritable "life of its own;" and the broader social and political contexts in which violence is employed as a means of resistance or empowerment by insurgents or as a means of domination or repression by state agencies and political elites. Indeed, sometimes the very distinction between "insurgent groups," state agencies, and paramilitary organizations is in question. In his 2007 review essay in Perspectives, "Inside Insurgency: Politics and Violence in an Age of Civil War," Sidney Tarrow observed that recent works by Kalyvas, Jeremy Weinstein, Elisabeth Jean Wood, and Paul Collier and Nicholas Sambanis "portend a new and more exciting stage in our understanding of . . civil wars" that is methodologically and analytically eclectic, and attentive to the interplays of history, structure and agency, and the complementarity of micro, meso, and macro levels of analysis. He indeed went further, suggesting that this work points toward the need to integrate the study of civil violence into the broader study of social movements and contentious politics.

In the past year or so, we have received a large number of research article submissions in this vein. Once a significant number of them made it through our review process, we decided to run them together in a special issue broadly centered on the theme of "violence and politics," 
and to complement them with some equally strong "Reflections" essays and specially commissioned book review essays and symposia. Each of these research articles was submitted separately and reviewed individually according to our standard process of blind internal review leading to blind external peer review. At the same time, there are striking overlaps and complementarities between the articles that do, I believe, offer further evidence of the intellectual tendencies Tarrow observed. And indeed in recent years we have published a number of important pieces - most notably Mark Galeotti's "Global Crime: Political Challenges and Responses" (September 2011), the symposium on "The New US Army/Marine Corps Counterinsurgency Field Manual as Political Science and Political Praxis" (June 2008), and the symposium on Douglass North, John Wallis, and Barry Weingast's Violence and Social Orders: A Conceptual Framework for Interpreting Recorded Human History (March 2008) — that underscore the theoretical and practical importance of attending to the complexities of political violence, and also underscore the extent to which this topic exceeds the standard subfield and methodological divisions in our discipline.

Three of our research articles focus on aspects of "civil war," and the other three on the study of "genocide." Read together, these articles make clear that these topics, typically analyzed separately, are profoundly linked, and that they implicate even broader questions regarding the varieties of political order and political contention.

Our lead article, Paul Staniland's "States, Insurgents, and Wartime Political Orders," centers on the limits of both conventional macro-analyses of civil war outcomes and micro-analyses of violence on the ground. Staniland argues that while many scholars in fact acknowledge the complexity of politics within civil wars, they typically lack concepts for properly describing and explaining this complexity. He writes: "While scholars of civil war have studied varying relationships between armed actors and civilian populations, their fundamental assumption about the relationship between contending armed actors is that both sides are locked in a straightforward struggle for a monopoly of violence. As a result, political science lacks a conceptual language to even describe varying political orders in civil war, much less to explain them .... They overlook the diverse interactions between states and insurgents that construct political authority and control. State and non-state actors have both cooperative and conflictual relationships that create dramatic variation in who rules, and how, in war. These different wartime political orders in turn shape patterns of violence against civilians, governance and economics, and post-war politics." Staniland thus maps "a conceptual typology of wartime political orders." Focusing on the distribution of territorial control and the level of state-insurgent cooperation, he identifies six wartime political orders, ranging from collusion and shared sovereignty to spheres of influence and tacit coexistence to clashing monopolies and guerrilla disorder. Staniland calls for "scholars of civil conflict to think creatively about how politics works amidst violence," and observes that such creative thinking has both theoretical and policy implications. As he writes, "The range of orders during war is more varied than existing prescriptions realize and thus stable outcomes in conflict zones like Iraq and Afghanistan may not look anything like what conventional doctrines suggest. Informal bargains, collusive state-insurgent relationships, and shared sovereignty are often less costly and more enduring than trying to build strong states, an endeavor that integrally involves coercion, extraction, and centralization. The wartime political orders this article identifies point to interesting new avenues for conflict resolution."

Kristin M. Bakke, Kathleen Gallagher Cunningham, and L. J. M. Seymour's "A Plague of Initials: Fragmentation, Cohesion and Infighting in Civil Wars" develops a remarkably similar perspective. Yet whereas Staniland is interested in the "political orders" that develop amidst civil war violence, Bakke et al. focus on the disorder within insurgent groups. Their key contention is that "The internal politics of non-state groups have received increasing attention, with recent research demonstrating the importance of cohesion and fragmentation for understanding conflict dynamics. Yet there is little consensus on how to conceptualize fragmentation, the concept at the center of this agenda ... In this paper we conceptualize fragmentation along three constitutive dimensions: the number of organizations in the movement; the degree of institutionalization across these organizations; and the distribution of power among them.” Like Staniland, Bakke et al. are interested in furthering the growing empirical sophistication in the study of civil war by contributing to the development of more sophisticated concepts. As they write, "While a number of recent studies suggest that fragmentation plays a key role in conflict processes, ways of assessing fragmentation and its corresponding implications vary widely. This study aims to bring coherence to the emerging research program on fragmentation and armed conflict. Valid concepts are the starting point for sound theories ... yet research on fragmentation in civil wars has reached little consensus when it comes to this first step in theory building."

In "Terrorism and Civil War: A Spatial and Temporal Approach to a Conceptual Problem," Michael Findley and Joseph K. Young seek to promote greater integration of the theoretical literatures on civil war and terrorism by expanding on the implications of the most recent developments in geo-spatial modeling. Synthesizing a broad range of data regarding the incidence and location of terror events, they "map the intersection of terrorist events and civil war zones worldwide to determine the extent to which they coincide." Findley and Young draw upon and suggest further refinements to strategic approaches to the 
political uses of violence, contending that "forms of violent and non-violent action may need to be considered together to understand how contentious politics operate more generally." But their primary contribution is to demonstrate, in their own words, that "geospatial modeling techniques are a powerful tool to bring together a wide variety of seemingly different types of violence into a single analysis."

Ernesto Verdeja's "The Political Science of Genocide: Outlines of an Emerging Research Agenda" proceeds from a striking observation: while recent years have seen the rise of genocide studies as an interdisciplinary scholarly discourse, in part as a response to post-Cold War genocides in Bosnia and Rwanda, and the Balkans and Great Lakes Region of Africa more generally, this discourse is strangely and unfortunately segregated from the comparative analysis of violence in political science, and especially from recent developments in the study of civil war and political contention. Verdeja calls for a holistic approach to the study of political violence, and outlines a research agenda that "focuses on analyzing the conditions under which genocide is likely to occur, the multilevel processes of violent escalation and de-escalation, and the ways in which these processes are shaped by, connect to, reinforce, accelerate and impede one another." This agenda seeks to explain the variability in genocidal outcomes, but also to consider genocide as one possibility (or set of possibilities) on (the extreme end of) the broader spectrum of politicized violence.

In "Can There Be a Political Science of the Holocaust?" Charles King develops a very similar argument, though with a difference of emphasis, by focusing on a particular genocide- the Holocaust, the Nazi-perpetrated genocide that centered on (but was not limited to) what Raul Hilberg called "the destruction of the European Jews." For if the study of genocide has largely been sequestered from the broader study of violence in political science, the Holocaust has typically been treated as a special case even within the study of genocide. The reasons for this are complicated, and while King touches on some of them, the focus of his argument is the reasons why the Holocaust ought to be fully incorporated into political science as a topic of inquiry. King argues that it is intellectually unfortunate that political scientists have paid so little attention to the Holocaust, especially given the growth of "an enormous archival fund in many languages, comprising everything from oral testimonies to state-level paper trails, as well as a vast secondary literature in history and the cross-disciplinary field of Holocaust studies." King insists that the "normalization" of the Holocaust as a topic of social scientific inquiry can enhance our understanding of this twentieth century atrocity, which has come to assume such enormous symbolic and moral importance. But he also insists that "historically grounded work on the destruction of European Jewry can illuminate the microfoundations of violent politics, unpack the relationship between a ubiquitous violence-inducing ideology (antisemitism) and highly variable murder, and recast old questions about the origins and evolution of the Holocaust itself." By analyzing the Holocaust in terms of a broader set of theoretical concerns - "the interaction of state power, local communities, and violent mobilization in five areas: military occupation, repertoires of violence, alliance politics, genocidal policymaking, and resistance" - we can "enrich our understanding of the perennial self-destructiveness of states and societies."

Scott Straus's "Retreating from the Brink: Theorizing Mass Violence and the Dynamics of Restraint" is of a piece with the Verdeja and King articles in its insistence that genocide, while an extreme form of political violence, is nonetheless a form of political violence, and as such ought to be deconstructed, disaggregated, and analyzed as a contingent and variable political phenomenon. In making this case Strauss also offers an important substantive suggestion - that to understand the variability of genocidal outcomes, and to understand why certain situations that would seem especially conducive to such outcomes do not generate them, it is necessary to theorize the importance of "restraint" as a source of moderation and de-escalation. In his own words: "a critical missing dimension to studies of genocide but also more generally to the study of political violence is a methodological recognition of negative cases and a theoretical recognition of the dynamics of restraint that helps to explain such negative cases. That is, in addition to asking what causes leaders to choose to escalate violence, the paper argues that scholars should emphasize conditions that prompt moderation, de-escalation, or non-escalation." Straus thus outlines a "ladder of violence" in which political authorities may select from a variety of strategies and, focusing on micro, meso, and macro factors, he argues that genocide ought to be seen as one violent outcome among many possibilities on a full spectrum of violent and non-violent outcomes. And while he suggests that genocide is most likely to occur in extreme situations of insecurity and conflict, its rarity is due in part to the fact that its perpetrators confront sometimes powerful sources of political moderation and restraint.

While each of our research articles has policy implications, each is oriented primarily towards analytic concerns. Our two "Reflections" essays address, in different ways, the practice of political science in "at risk" situations of turmoil and violence. Both are occasioned by experiences linked to the practices of scholarly research and writing. But both are Reflections, in the true sense of the term, on the experiences, choices, and judgments involved in research, and on our relationship to our scholarly objects of investigation, rather than on the objects of inquiry themselves or on the methods most appropriate to the study of these objects (in this way these pieces are related to, but 
subtly different from, pieces we recently have published by Andreas Schedler on "Judgment and Measurement in Political Science" and Peter Katzenstein and Rudra Sil on "Analytic Eclecticism"). In this regard they are models of what we hope to accomplish with our "Reflections" essays.

Charli Carpenter's "'You Talk Of Terrible Things So Matter-of-Factly in This Language of Science': Constructing Human Rights in the Academy" is an extraordinary essay, in my view among the very best things ever published in Perspectives. It offers a careful, nuanced, and extended reflection on Carpenter's recently published Forgetting Children Born of War, a book on the human rights of children born of rape and exploitation in conflict zones, which seeks to explain why children born of war rape had received so little attention from advocacy organizations aiming to protect war-affected children (the book itself is discussed in a review essay by Christopher Blattman in this issue). An earlier version of the essay was itself originally written as part of the book but, as Carpenter explains, it was decided-i.e., on the basis of collegial advice and editorial encouragement she decided — that the book would work "best" without it. As Carpenter writes: "I found as I completed my work on Bosnia that the process of researching human rights is in fact intimately connected with the practice of constructing human rights in and around a variety of policy arenas. Far from existing outside their subject matter, human rights intellectuals are part of the human rights movement and actively shape it, whether or not our methodology demands it. But my colleagues did not advise me to explicitly account for this factor in my research or analyze the academy as a source of momentum or resistance to new human rights issues. To turn the spotlight on the academy itself would have been to breach professional norms within the discipline, norms that tell us 'real' research is distinct from advocacy. I increasingly realized that this very dynamic itself required analysis."

Carpenter writes powerfully about the kinds of things that we political scientists typically take for granted, the kinds of choices we typically make about our research practice largely without thinking them through-which is ironic, given the extensive and sometimes obsessive attention we tend to pay to questions of "research design" and "data analysis." It would be condescending to suggest that her essay should be read carefully by all graduate students, for I would submit that the essay should be read carefully by all political scientists whatever their status. The essay moves carefully through a range of important research decisions with ethical consequences. In part I, "Constructing human rights research in the academy," Carpenter discusses the challenges and judgments essential to articulating a research question; obtaining human subjects clearance and then dealing with a range of human "subjects" whose lives are touched and sometimes strongly influenced by their function in our research; data collection more generally; and the kinds of considerations and com- promises that are often necessary in order to successfully place research in suitably prestigious academic publications. In part II, "Constructing human rights practice through scientific research," she discusses the very real challenges faced by scholars who successfully complete research that is interesting and policy relevant: "hanging out on the theory/policy divide," circulating scholarly outputs (i.e., the things we write and publish) among policymakers and the broader public; handling the media; consulting with governmental and non-governmental agencies interested in the topic of research; and thinking through a set of serious "epistemological tradeoffs" that can be boiled down to the following question: "is it more important to me that my work is taken seriously by my disciplinary colleagues and scores points in the profession, or that it makes a positive difference in the world, advancing values - the humane treatment of vulnerable populations? Human freedom and dignity? - that I consider of profound and perhaps paramount importance?" Carpenter's essay is both strongly argued and deeply personal. It gives voice to one serious scholar's careful reflection on the meaning of her work and the personal choices this work entails, in a way that is offered to colleagues as a provocation and an incitement to reflection. At the same time, it is less interested in prescribing how others should think or choose than it is in insisting in the important of thoughtfulness about what we do. As Carpenter writes: "It is . . impossible and irresponsible to pretend that the research process itself has not influenced the very communities of practice we study. Acknowledging this required me to reflect on my own role in the human rights network, and that of like-minded colleagues and academia as a whole, as I completed the manuscript for my former book and my new one. For no scholarly work-least of all one that plays at the boundary between politik and wissenschaft — can be fully understood without an honest interrogation of the author's relationship to her subject matter, mediated through the institutions in which she is embedded." Such interrogation is important for the intellectual integrity of the work that we do. It is also a potential source of empowerment. For, as Carpenter concludes: "Political scientists who write about, interpret and reconceive human rights have a kind of political power, power that we too seldom acknowledge as we play with philosophical and theoretical ideas for personal and professional gain; power which our training gives us few skills with which to wield wisely."

Carpenter's essay is perfectly complimented by Christopher Blattman's review essay, "Children and War: How 'Soft' Research Can Answer the Hard Questions in Political Science," which discusses Carpenter's Forgetting Children Born of War along with Scott Gates and Simon Reich's anthology Child Soldiers in the Age of Fractured States and Romeo Dallaire's They Fight Like Soldiers, They Die Like Children. Blattman's piece is an extended essay in its own right. In discussing the books under review it raises a 
number of important questions, about the plight of particularly vulnerable communities in war zones, the complexities of being both a victim and a perpetrator of war crimes, and the ethical challenges of taking such topicssuch subjects —as the object of scholarly research. One of the most interesting things about Blattman's essay is that it offers a very subtle and self-aware discussion of the value of both "softer" interpretive approaches and "harder" rationalist approaches. Blattman makes a strong case for the importance of recent formal modeling of "the industrial organization of rebellion," and in particular he praises Jens Advig and Scott Gates' chapter in the Gates and Reich volume for the way it employs models of labor markets in labor economics to understand the variable uses of child soldiers in war. Blattman indeed concludes by suggesting that such formal approaches - and indeed more rigorous, interdisciplinary, and theoretically sophisticated work from a range of approaches-promise not simply stronger explanatory models, but more grounded and therefore relevant policy advice as well.

Our second "Reflections” essay, Lisa Anderson's “'Too Much Information?' Political Science, the University and the Public Sphere," is also concerned with the meaning, relevance, and traction of social scientific knowledge. Anderson is an accomplished political science scholar with extensive experience as an academic institution builder, through her work with the Social Science Research Council, the Middle East Studies Association (of which she is a past President), Human Rights Watch, and the Council on Foreign Relations, and her service as Dean of Columbia University's School of International and Public Affairs. She currently serves as President of the American University in Cairo, and her essay takes its bearings from the recent experience of the Arab Spring, and especially the ongoing events in Cairo's Tahir Square, which abuts the university's campus. Writing from Cairo, Anderson addresses what she calls "the particularly vexed relationship of the American university-based political scientist with the policy world and wider public sphere." Her piece is a powerful cri de coeur for greater reflexivity about our institutional locations and the challenges and opportunities these afford our work. As she argues: "a transformation in the availability of information has eroded authority, undermined hierarchies and upended the organizational mechanisms by which knowledge is developed, collected and disseminated around the world. This has meant a decline in interest in and deference to universities and university-based research and has lessened popular estimates of what the university-based political scientist has to offer to students, citizens, politicians and policy makers. If we as political scientists are to regain the esteem of the public, it will be because we have engaged them on new terms- the terms of a twenty-first century in which information is abundant and the sort of formal credentials we university-based political scien- tists have all worked so hard to secure are relatively inconsequential. What we must be prepared to do is engage our students and colleagues, as well as our fellow citizens and policymakers, in the relatively informal, nonhierarchical networks of collaboration, reciprocity and shared wisdom in which the next generations are already beginning to live, learn and work."

The promotion of reflexivity within the political science discipline about the work that we do and the ways that this work matters is one of the primary editorial goals of Perspectives. Our principal means of doing this is to publish excellent research that is broad and to foster serious dialogue within the political science profession. But our hope is that by broadening the discipline from within, we can also facilitate constructive scholarly discussions beyond the discipline. With this goal in mind, we have decided to introduce a new format featuring review essays on important scholarly books from other disciplines, and to provocatively entitle these features "Undisciplined." Our inaugural entry in this category is Daniel Chirot's "Looking Into the Abyss," a review of historian Timothy Snyder's Bloodlands: Europe Between Hitler and Stalin. Snyder's book has received extraordinary attention in the broad literary press in the US and in Europe, and the topic it addresses - Soviet and Nazi totalitarianism and especially their interactions in the period 1939-1945-fits perfectly with the broad theme of this issue. As Chirot nicely summarizes, "[Snyder] argues that while many works of historical scholarship have documented the mass murders that Hitler and Stalin perpetrated in this area, in general these works ignore the complex dynamics of interaction and competition between these two murderous regimes that played out on this territory and that caused so many civilian deaths. As Snyder argues, the focus of his analysis 'arises not from the political geography of empires but from the human geography of victims. The bloodlands were no political territory, real or imagined; they are simply where Europe's most murderous regimes did their most murderous work.'”

Chirot's piece centers on the role of murderous ideologies, but also on the complex relationships between leaders and followers, and between perpetrators and bystanders, in sustaining murderous geo-political and military policies such as those pursued by Stalin and Hitler. Our symposium on Kristen Renwick Monroe's Ethics in an Age of Terror and Genocide: Identity and Moral Choice (Princeton, 2012) focuses on the social psychology of perpetrators, bystanders and rescuers of genocide, and whether or not these different forms of conduct can be explained in terms of different kinds of personality or sense of identity. Monroe's study draws on over 100 interviews with Dutch and German survivors of World War II that she conducted starting in 1988, and centers on very carefully presented narratives of five individuals, each of whom took a different path during the war and 
subsequently reflected (in structured interviews) very differently upon the path they had taken. Monroe argues that "Ethical acts emanate not so much from conscious choice but rather from deep-seated instincts, predispositions, and habitual patterns of behavior that are related to our central identity," and that whether or not one is likely to perpetrate, support, witness, or oppose genocide is strongly shaped by one's sense of self-worth and one's confidence about one's connections to others. Our symposium includes terrific commentaries by Lee Ann Fujii, Joan C. Tronto, and Kristina E. Thalhammer, who raise questions both about Monroe's model of psychology and the extent to which it is the context in which individuals are embedded rather than their sense of personal identities that best explains their conduct.

As I hope should be very clear, the materials thus far summarized represent a wide range of approachesconceptual, interpretive, and formal, psychological, microanalytic, and macro-historical - to the study of violence and especially to the understanding of the dynamics of large-scale civil violence. This diversity of approaches is visibly reflected in the wide range of books featured in our special review section on Violence and Politics.

A number of these books deal with questions of interstate rivalry and the dynamics of competition and war of the kind that would conventionally appear in our "international relations" review section: Jack S. Levy and William R. Thompson's The Arc of War: Origins, Escalation, and Transformation, Thomas Lindeman's Causes of War: The Struggle for Recognition, Branislav L. Slantchev's Military Threats: The Costs of Coercion and the Price of Peace, and Karen E. Smith's Genocide and the Europeans. A number deal with the ethics of violence and of non-violent resistance: Dustin Ells Howes' Toward a Credible Pacifism: Violence and the Possibilities of Politics, Helen M. Kinsella's The Image before the Weapon: A Critical History of the Distinction between Combatant and Civilian, Sharon Erickson Nepstad's Religion and War Resistance in the Plowshares Movement, Stefaan Walgrave and Dieter Rucht's The World Says No to War: Demonstrations Against the War on Iraq, David Fisher's Morality and War: Can War Be Just in the Twenty-First Century? and Howard M. Hensel's edited volume The Prism of Just War: Asian and Western Perspectives on the Legitimate Use of Military Force.

And a number deal with civil conflict and with the challenges of peace-building and reconciliation that emerge in the wake of civil wars and revolutions. Of particular note here is Ernesto Verdeja's review of Remaking Rwanda: State Building and Human Rights after Mass Violence, edited by Scott Straus and Lars Waldorf; Ana Stilz's review of Judging State-Sponsored Violence, Imagining Political Change by Bronwyn Lebow; Arie M. Kacowicz's triple review of Ungoverned Spaces: Alternatives to State Authority in an Era of Softened Sovereignty, edited by Anne L. Clunan and Harold A. Trinkunas, Proxy Warriors: The Rise and Fall of State-
Sponsored Militias, by Ariel I. Ahram, and Strengthening Peace in Post-Civil War States: Transforming Spoilers into Stakeholders, edited by Matthew Hoddie and Caroline A. Hartzell; Benjamin Gregg's review of Human Rights and Memory, by Daniel Levy and Natan Sznaider, Humanitarianism and Modern Culture, by Keith Tester; and Katherine Hite's review of Accounting for Violence: Marketing Memory in Latin Amer$i c a$, edited by Ksenija Bilbija and Leigh A. Payne, and Reckoning with Pinochet: The Memory Question in Democratic Chile, 1989-2006 by Steve J. Stern.

For a variety of reasons books on American politics are heavily underrepresented in our special section. But we do include reviews of a number of books that make vividly clear that in the US "domestic politics" and "foreign policy" are closely intertwined and inextricably linked to questions of violence: James P. Pfiffner's Torture as Public Policy: Restoring U.S. Credibility on the World Stage, Amanda DiPaolo's Zones of Twilight: Wartime Presidential Powers and Federal Court Decision Making, Anthony DiMaggio's When Media Goes to War: Hegemonic Discourse, Public Opinion, and the Limits of Dissent, Matthew A. Baum and Tim J. Groeling's War Stories: The Causes and Consequences of Public Views of War, Ole R. Holsti's American Public Opinion on the Iraq War, and Austin Sarat and Nasser Hussain (eds.), When Governments Break The Law: The Rule of Law and the Prosecution of the Bush Administration.

There is, finally, our Critical Dialogue on the topic of retributive justice and reconciliation, featuring James $\mathrm{L}$. Gibson and Monika Nalepa. Gibson, author of Overcoming Historical Injustices: Land Reconciliation in South Africa, centers his account of transitional justice on the theme of "socio-tropic fairness" and the need of transitional regimes to respond to mass demands for justice. Nalepa's Skeletons in the Closet: Transitional Justice in Post-Communist Europe, on the other hand, develops a dynamic strategic model of transitional justice in which policy variation is explained in terms of the jockeying for power of former-Communist and successor political elites. For Nalepa the most important factor is not mass public opinion regarding fairness, but the ability of competing elites to publicize or threaten to publicize "skeletons in the closet," information or innuendo regarding complicity under the old regime. The dialogue between Gibson and Nalepa touches a range of issues: land policies in South Africa versus "lustration" in Central Europe; the dynamics between political elites, parties, and masses under conditions of political transition; and the relative strengths and weaknesses of rational choice versus behavioralist approaches. We have been running these Critical Dialogues for almost seven years. We always try to identify clearly excellent books on important topics, and to bring together authors whose critical dialogues can be instructive for our readers by demonstrating the possibilities for substantive conversation across standard methodological, regional, and subfield divides. In this case the books seemed so well matched that I failed to note 
something important when I organized the discussion: that while one of our discussants is a well-known senior scholar, the other is an untenured Assistant Professor. We work very hard to avoid such imbalances in our dialogues, because we take very seriously the need to promote the professional development of junior colleagues. It is a testament to the quality of Monika Nalepa's book (which I am pleased to note has recently won the 2011 Best Book Award from APSA's Comparative Democratization section) that I made this oversight. I am very pleased by the quality and collegiality of this Dialogue. But I want to make very clear that this imbalance was my mistake, and that it is something we work hard-and will work even harder in the future-to avoid.

As readers can see, this is a very rich issue. We were able to put it together in a fairly short time frame primarily because we are fortunate to have lots of terrific pieces written by authors who have been extremely cooperative. Special thanks go to three people who went beyond the call of duty in helping with this issue: board members Stathis Kalyvas and Virginia Page Fortna, both of whom read many of the papers published in this issue and offered sage editorial advice; and Adrian Florea, a terrific young scholar who is our Editorial Assistant responsible for the
International Relations book section. Adrian has worked indefatigably on this issue, spreading the word about our interest in "IR" topics at the MPSA and ISA meetings, commissioning reviews, and reading most of the submissions published in this issue. Indeed, our entire staff worked beyond the call of duty in readying this issue for production. Margot Morgan, our Book Review Managing Editor, points out that this issue contains reviews of 106 books_-including 45 books on our special theme of violence and politics - which is by far the largest number of books we have ever covered in a single issue. A shout-out to my staff-Margot, Adrian, Emily Hilty, Rafael Khachaturian, Hicham Bou Nassif, Katie Scofield, Beth Easter, and of course Managing Editor James Moskowitz-for their work. Thanks also to our copyeditors.

A reminder: our September issue will have a special New Orleans theme, and is scheduled to appear before this year's APSA Conference in New Orleans. It will be the basis of the Perspectives theme panel at the conference. We hope many readers will try to attend the panel, which is a wonderful opportunity for our journal, and its editorial staff and board, to engage our readers in substantive scholarly conversation. 


\section{Statement of Mission and Procedures}

Perspectives on Politics seeks to provide a space for broad and synthetic discussion within the political science profession and between the profession and the broader scholarly and reading publics. Such discussion necessarily draws on and contributes to the scholarship published in the more specialized journals that dominate our discipline. At the same time, Perspectives seeks to promote a complementary form of broad public discussion and synergistic understanding within the profession that is essential to advancing scholarship and promoting academic community.

Perspectives seeks to nurture a political science public sphere, publicizing important scholarly topics, ideas, and innovations, linking scholarly authors and readers, and promoting broad reflexive discussion among political scientists about the work that we do and why this work matters.

Perspectives publishes work in a number of formats that mirror the ways that political scientists actually write:

Research articles: As a top-tier journal of political science, Perspectives accepts scholarly research article submissions and publishes the very best submissions that make it through our double-blind system of peer review and revision. The only thing that differentiates Perspectives research articles from other peer-reviewed articles at top journals is that we focus our attention only on work that in some way bridges subfield and methodological divides, and tries to address a broad readership of political scientists about matters of consequence. This typically means that the excellent articles we publish have been extensively revised in sustained dialogue with the editor-me- to address not simply questions of scholarship but questions of intellectual breadth and readability.

"Reflections" are more reflexive, provocative, or programmatic essays that address important political science questions in interesting ways but are not necessarily as systematic and focused as research articles. These essays often originate as research article submissions, though sometimes they derive from proposals developed in consultation with the editor in chief. Unlike research articles, these essays are not evaluated according to a strict, doubleblind peer review process. But they are typically vetted informally with editorial board members or other colleagues, and they are always subjected to critical assessment and careful line-editing by the editor and editorial staff.

Scholarly symposia, critical book dialogues, book review essays, and conventional book reviews are developed and commissioned by the editor in chief, based on authorial queries and ideas, editorial board suggestions, and staff conversations.

Everything published in Perspectives is carefully vetted and edited. Given our distinctive mission, we work hard to use our range of formats to organize interesting conversations about important issues and events, and to call attention to certain broad themes beyond our profession's normal subfield categories.

For further details on writing formats and submission guidelines, see our website at http://www.apsanet.org/ perspectives/ 